\title{
ASSESSMENT OF SPECIES DIVERSITY AND DISTRIBUTION OF WOODY SPECIES ON SELECTED PLOTS IN OLOKEMEJI FOREST RESERVE, OGUN STATE, NIGERIA
}

\author{
*Taiwo, D. M., Udoh, S. I., Olaoti-Laaro, S. O., Jeminiwa, O. R., Jeminiwa, M. S. \\ Forestry Research Institute of Nigeria, Ibadan. \\ *Corresponding author's email: taidamar20@gmail.com; Tel.: +2348167754312 \\ (Received: $11^{\text {th }}$ April, 2020; Accepted: $10^{\text {th }}$ August, 2020)
}

ABSTRACT

\begin{abstract}
The Assessment of forest species composition and species diversity is essential in understanding the status of tree population and diversity for conservation purpose. Olokemeji forest reserve is situated in the lowland rain forest of south-western Nigeria and it occupies a total land area of $58.88 \mathrm{~km}^{2}$. Six study plots of $50 \mathrm{~m}^{2}$ each were randomly selected and designated as Frequently Burnt Plot 1, Frequently Burnt Plot 2, Harvested Plot, Unharvested Unburnt Plot, Arable Plot 1 and Arable Plot 2 for the purpose of assessment of species diversity and distribution of woody species. Seven species of trees were identified belonging to five families. One hundred and eighty two stands were enumerated, with Unharvested Unburnt Plot having the highest number of trees at 50. The dominance index for the woody flora was 1 in Frequently Burnt Plot 1 and 2 as well as Arable Plot 1 and 2 except for the Harvested Plot that had the lowest (0.29) while the Unharvested Unburnt Plot had 0.75. Highest species richness was recorded at the Harvested Plot at 0.71 . The species diversity in Harvested Plot was low (1.54), while it was extremely low in Unharvested Unburnt Plot (0.43). Evenness index was lowest in the Unharvested Unburnt Plot at 0.43 . Tectona grandis had the highest relative importance value in the Frequently Burnt Plot 1. The low species richness and species diversity is a direct indication of anthropogenic interference in the study plots and the forest reserve; this requires urgent mitigation to prevent a total loss of its structure and function as expected of a forest reserve.
\end{abstract}

Keywords: Species, Diversity, Evenness, Anthropogenic, Forest, Dynamics

\section{INTRODUCTION}

Species composition and diversity alongside adequate knowledge of the distribution of tree species in forest reserves reveal the status of the forest. Tree species composition and distribution is very helpful in understanding the status of forest stands, regeneration, and diversity for conservation purposes. The structure of forest estates largely depends on the ecological characteristics of sites, species diversity and regeneration status of tree species. Quantitative information on composition, distribution, or abundance of trees species is of key importance in understanding composition and structure of a forest estate; and also very useful for decisionmaking, planning and implementation of conservation strategy of the forest reserves (Amonum etal., 2019).

Forest ecosystems are home for biodiversity and they provide food and other important materials for survival in terrestrial ecosystems. But, they are threatened from time to time mainly as a result of anthropogenic activities such as deforestation for agricultural activities, overgrazing, construction materials, timber production, fire wood, road construction, charcoal production and medicinal values (Yonas, 2001; Getachew and Demel, 2005; Bajpai et al., 2017). These temporary benefit oriented deforestation is followed by land degradation and soil erosion which result in biodiversity loss (Feyera, 2006: Feyera and Denich, 2006; Tadesse, 2008). Destruction of vegetation cover causes environmental degradation, climate change, drought, depletion of natural resources and food shortage. These are the major issues of national and global concern in recent years and it calls for urgent mitigation.

Component of vegetation must therefore be constantly monitored and managed in order to direct succession processes towards maintaining species and habitat diversity (Athua and Pabi, 2013). Abundance or diversity of tree species is an important aspect in forest ecosystem and is also basic to forest biodiversity. Forest stand structure is a key element in understanding forest ecosystems and also an important element of stand biodiversity (Ozcelik et al, 2008). 
Olokemeji forest reserve is currently degraded due to human impacts such as logging, excessive burning and farming activities within the reserve, therefore the aim of this study was to access the woody flora composition, diversity and structure of some selected plots of Olokemeji forest reserve for better management and policy making.

\section{MATERIALS AND METHODS}

\section{THE STUDY AREA}

\section{Location of the Study Site}

Olokemeji forest reserve occupies a total land area of $58.88 \mathrm{~km}^{2}$.The reserve, which was established in 1899 is the second forest reserve in Nigeria. The forest reserve is situated between latitude $70^{\prime \prime} 25^{\circ} \mathrm{N}$ $30^{\circ}$ to $70^{\prime \prime} 39^{\circ} \mathrm{N}$ and Longitude $30^{\prime \prime} 32^{\circ} \mathrm{E}$ to $30^{\prime \prime}$ $44^{\circ} \mathrm{E}$. The site lies approximately $32 \mathrm{~km}$ west of Ibadan, and $35 \mathrm{~km}$ north-east of Abeokuta
(Akinsoji and Sowemimo, 2005).

Olokemeji forest reserve is among the forest reserves in the country where relics of tropical rain forest could be found. Already forest plantation establishment, bush burning, shifting cultivation and other development features have occurred in the reserve resulting in loss of biodiversity (Ogunleye et. al., 2004). On the alluvial soils are found a floristically distinct vegetation type dominated by an abundance of Manilkara multinervis, Diospyros mespiliformis and Nesogordonia papaverifera. The derived savanna found north and west of the reserve, consists of species such as Daniellia oliveri, Vitellaria paradoxa, Parkia biglobosa, Lophira lanceolata and Pterocarpus erinaceus (Ogunleye et al., 2004).The physical features, climate and vegetation of the reserve have been described by Hopkins (1972).

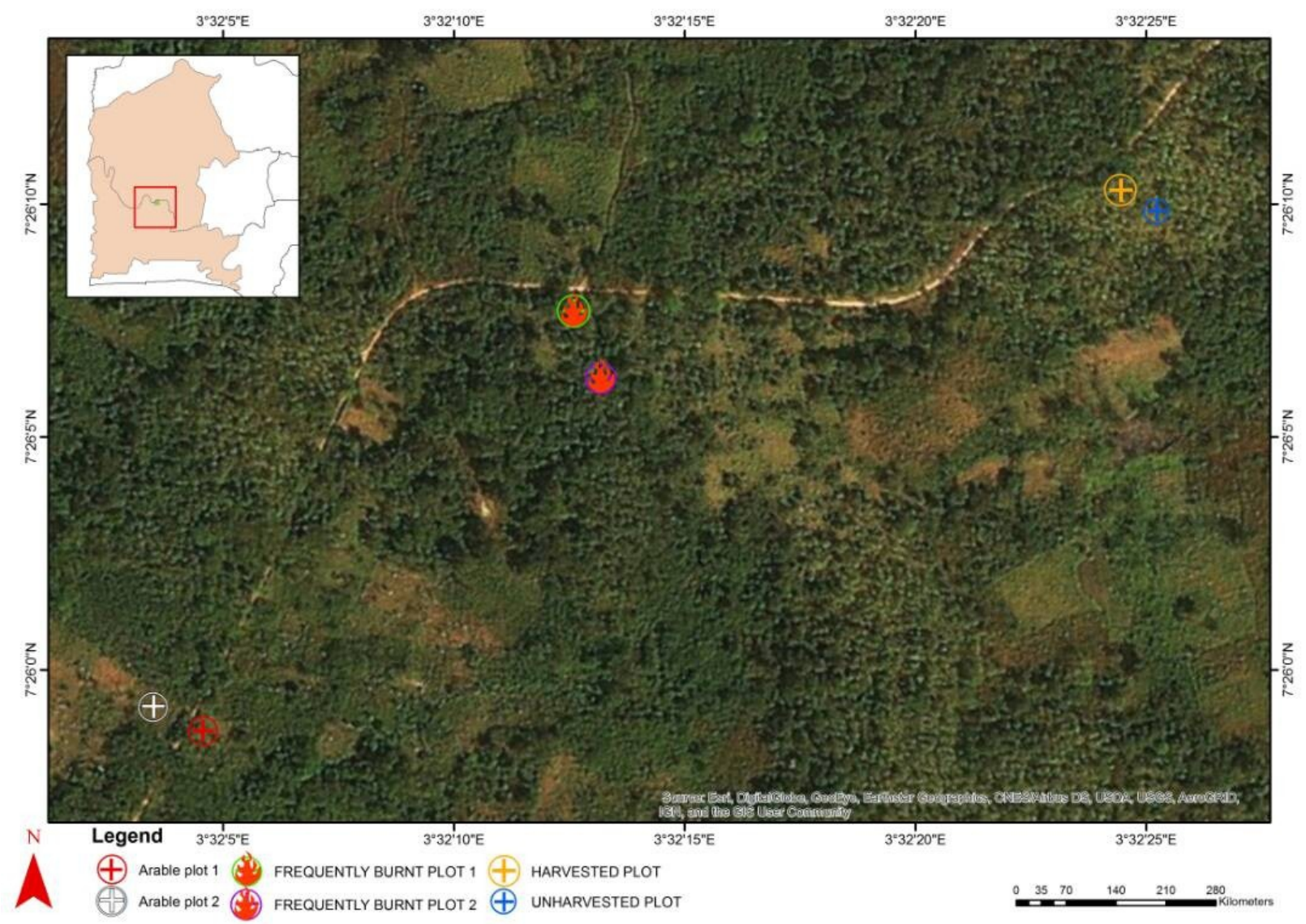

Figure 1: Location of Study Plots in Olokemeji Forest Reserve, Ogun State, Nigeria 


\section{Data Collection}

This study was carried out between November 2016 and May 2017. A plot each of dimension 50 m X $50 \mathrm{~m}$ was established in six randomly chosen locations in the forest reserve, study plots were laid out using a measuring tape demarcated with wooden pegs. In all the six study plots, all tree heights $\geqslant 5 \mathrm{~m}$ girth and height $\geqslant 10 \mathrm{~cm}$ were identified following the method of Hutchinson and Dalziel (1954) and enumerated to determine the mean diameter at breast height, mean basal area and mean heights. The composition of woody species data of Olokemeji forest reserve was collected and each species were counted to determine their relative importance value (RIV).

Table 1: Location and Weather of Study Plots in Olokemeji Forest Reserve, Ogun State, Nigeria

\begin{tabular}{|c|c|c|c|c|}
\hline Study Plots & Temperature & $\begin{array}{l}\% \text { Relative } \\
\text { Humidity }\end{array}$ & $\begin{array}{l}\text { Longitude and } \\
\text { Latitude }\end{array}$ & Elevation \\
\hline $\begin{array}{l}\text { Frequently } \\
\text { Burnt Plot } 1 \\
\text { (FT1) }\end{array}$ & $32.2^{\circ} \mathrm{C}$ & 82.8 & $\begin{array}{l}\mathrm{N} 07.43547^{\circ} \\
\mathrm{E} 003.53684^{\circ}\end{array}$ & $133 \mathrm{~m}$ \\
\hline $\begin{array}{l}\text { Frequently } \\
\text { Burnt Plot } 2 \\
\text { (FT2) }\end{array}$ & $31{ }^{\circ} \mathrm{C}$ & 85.2 & $\begin{array}{l}\mathrm{N} 07.4350^{\circ} \\
\mathrm{E} 003.5370^{\circ}\end{array}$ & $128 \mathrm{~m}$ \\
\hline $\begin{array}{l}\text { Harvested } \\
\text { Plot (HP) }\end{array}$ & $33.2^{\circ} \mathrm{C}$ & 67.6 & $\begin{array}{l}\mathrm{N} 07.4361^{\circ} \\
\mathrm{E} 003.5401^{\circ}\end{array}$ & $131 \mathrm{~m}$ \\
\hline $\begin{array}{c}\text { Unharvested } \\
\text { Unburnt Plot } \\
\text { (UP) }\end{array}$ & $33.5^{\circ} \mathrm{C}$ & 66.4 & $\begin{array}{l}\mathrm{N} 07.4360^{\circ} \\
\mathrm{E} 003.5403^{\circ}\end{array}$ & $128 \mathrm{~m}$ \\
\hline $\begin{array}{l}\text { Arable Plot } 1 \\
\text { (AP1) }\end{array}$ & $35.8^{\circ} \mathrm{C}$ & 70.8 & $\begin{array}{c}\mathrm{N} 07.4329^{\circ} \\
\mathrm{E} 003.53460^{\circ}\end{array}$ & $106 \mathrm{~m}$ \\
\hline $\begin{array}{c}\text { Arable Plot } 2 \\
\text { (AP2) }\end{array}$ & $36.1{ }^{\circ} \mathrm{C}$ & 68.5 & $\begin{array}{c}\mathrm{N} 07.4333^{\circ} \\
\mathrm{E} 003.53504^{\circ}\end{array}$ & $108 \mathrm{~m}$ \\
\hline
\end{tabular}

\section{DATA ANALYSIS}

Species diversity was obtained from diversity indices using Paleontological statistics software (PAST 2.14) (Hammer et al., 2011). The following parameters were taken into account from the diversity index analysis:

Abundance

Species abundance is used to measures the quantity or number of each species and families in an a particular quadrant/ plot (Aregheore, 2009)

$P i=\frac{N i}{N}$

With Ni being the abundance of the $i^{\text {th }}$ species in the sample, and

$\mathrm{N}=$ the total number of individuals.

Dominance

This is a measure of the prevalence of a particular species in relation to other species in an ecosystem. Dominance shows the species with superior competitive ability to others regarded as inferior based on competition (Stephane et al., 2009). It is the most of the population in a community and the effect on any population is mainly influenced by the species of high dominance. It usually ranges from zero to one in value where one signifies high dominance.

Species Richness

Species richness was computed using the procedure outlined by Spellerberg (1991) and Magurran (2004) as used by Oluwatosin and $\operatorname{Jimoh}(2016)$ :

$D=\frac{S}{\sqrt[2]{n}}$ 
Where: $\mathrm{D}=$ species richness (Margalef index), $\mathrm{S}=$ the total number of species and $n=$ the total number of individuals.

Evenness

It is the relative abundance of species per unit area. This was used to measure the similarity of relative abundance of species within sample plots. It was estimated with the Pielou's evenness index (J) as

$J=\frac{H}{S}$

where $\mathrm{H}=$ Shannon diversity index and $\mathrm{S}$ is species richness as previously defined (Hopper et al., 2005).

\section{Shannon-Weiner}

This is a measure proposed by Claude Shannon and accounts for both abundance and evenness of species present in an ecosystem (Kent and Coker, 1992 and Olubode et al., 2011). It measures overall community characteristics. It is higher when there are more species, indicating greater diversity. Shannon-Weiner Index of diversity $\left(\mathrm{H}^{\prime}\right)$ was calculated following Kent and Coker (1992) and Magurran (2004):

$H^{\prime}=-\sum_{i=1}^{S} p i \ln p i$

Where $H^{\prime}$ value of Shannon -Weiner diversity index.

$\mathrm{s}=$ Number of species in community,

$\mathrm{i}=\mathrm{i}$ th species

$\mathrm{pi}=$ proportion of individuals in the ith species, $\ln =$ natural logarithm

Relative Importance Value (RIV)

The Relative Importance Values (RIV) of all species were determined following the method of Olubode et al., (2011). It was computed as:

$\mathrm{RIV}=\frac{\text { Relative Frequency }}{\text { Relative Density }} \times 100$

Where:

Frequency is the number of occurrence of a species in a set of quadrats or area.

Relative Frequency is a relative value of occurrence of a species in a set of quadrats to total species in the quadrats.

Relative Frequency $=\frac{\text { Frequency of a species }}{\text { Frequency of other species }} \times 100$
Density is the quantity of individual species to abundance of species per unit area.

Density $=\frac{\text { Quantity of species }}{\text { Quadrant size or Number of quadrants laid }}$

Relative density was obtained using the formula:

Relative Density $=\frac{n i}{N} \times 100$

Where $\underline{n i}$ is the number of individual species

$\mathrm{N}$ is the total number of different species in the entire population

\section{RESULT}

\section{Composition of Woody Flora}

A total of seven species were enumerated belonging to five families in the quadrats laid in six plots. Three tree species were enumerated in Fabaceae family; Verbaceae and Combretaceae family had one species as well as family Leguminoseae and Meliaceae. Members of the Fabaceae families enumerated were Delonix regia, Albizia lebbeck, Albizia sygia. Gliricidia sepium belongs to family Leguminoseae and Tectona grandis belongs to Verbaceae family, Tectona grandis was dominant in Frequently Burnt Plot 1, Frequently Burnt Plot 2, Harvested Plot and Unharvested Unburnt Plot.

\section{Relative Importance Value (RIV) of tree species in Study Plots of Olokemeji Forest Reserve, Ogun state, Nigeria}

Frequently Burnt Plot 2 had the highest relative importance value for Tectona grandis at 17.22, followed by Unharvested Unburnt Plot which had a RIV of 16.45 and Frequently Burnt Plot 1 recorded 15.3 as relative importance value of Tectona grandis. Harvested Plot had the least relative importance value of Tectona grandis (5.73).

Albizia sygia had RIV of 11 in the Harvested Plot, 3.41 in the Arable Plot 1 and 2.56 in the Arable Plot 2. Azadiracbta indica had RIV of 5.68 in the Harvested Plot and 2.84 in the Unharvested Unburnt Plot. Anogeissus leiocarpus had RIV of 6.05 in the Harvested Plot. Albizia lebbeck had RIV of 4.93 in the Unharvested Unburnt Plot. Delonix regia and Gliricidia sepium had RIV of 4.39 in the Unharvested Unburnt Plot and Harvested Plot respectively (Table 2). 
Table 2: Relative Importance Value of Tree Species in Study Plots of Olokemeji Forest Reserve, Ogun State, Nigeria

\begin{tabular}{lcccccc}
\hline \multicolumn{1}{c}{ Species } & FT1 & FT2 & HP & UP & AP1 & AP2 \\
\hline Tectona grandis & 15.31 & 17.22 & 5.73 & 16.45 & 0 & 0 \\
Albiria sygia & 0 & 0 & 11 & 0 & 3.41 & 2.56 \\
Azadirachta indica & 0 & 0 & 5.68 & 2.84 & 0 & 0 \\
Anogeissus leiocarpus & 0 & 0 & 6.05 & 0 & 0 & 0 \\
Albiria lebbeck & 0 & 0 & 0 & 4.95 & 0 & 0 \\
Delonix regia & 0 & 0 & 0 & 4.39 & 0 & 0 \\
Gliricidia sepium & 0 & 0 & 4.39 & 0 & 0 & 0 \\
\hline
\end{tabular}

Footnote: Frequently Burnt Plot = FT; Harvested Plot $=$ HP; Unharvested Unburnt Plot $=$ UP; Arable Plot $=$ AP

\section{Diversity Indices of Tree Species in Study Plots of Olokemeji Forest Reserve, Ogun State, Nigeria}

The species diversity of the woody flora depicted distinct values for the study plots and the number of individual species (abundance) were seven, One hundred and eighty two tree stands were enumerated, with Unharvested Unburnt Plot having the highest number of trees stands at 50, next to Unharvested Unburnt Plot was Frequently Burnt Plot 2 with 45 number of trees, Frequently Burnt Plot 1 and Harvested Plot had 40 individual tree species while Arable Plot1 and Arable Plot 2 had 4 and 3 individual trees respectively. Dominance index was moderately high across the six study plots, with Frequently Burnt Plot 1, Frequently Burnt Plot 2, Arable Plot 1 and Arable Plot 2 having dominance index 1, which depicts that a particular tree species can be found in these study plots.

The Unharvested Unburnt Plot had a dominant index of 0.75 which depicts that there is a dominant tree species in the sample plot, while the Harvested Plot had 0.29 dominant index which means that there is less dominance among the tree species found in Harvested Plot. Simpson index otherwise known as species richness is low across the study plots except in Harvested Plot where the highest species richness was recorded at 0.71 ; this was followed by Unharvested Unburnt Plot where 0.25 was recorded which depicts very low species richness. In Frequently Burnt Plot 1, Frequently Burnt Plot 2, Arable Plot 1 and Arable Plot 2 had no species richness because they were dominated by just one woody species. The rarefaction curve describes the species richness of each study plots assessed during this study where the Harvested Plot had the highest species richness (Figure 2). The Shannon-Weiner index was low across all the study plots, which depicted low diversity of tree species. Evenness index was highest in the Harvested Plot and low in the Unharvested Unburnt Plot, while the evenness indices of the other plots depict the presence of only one species (Table 3). 
Table 3: Species Diversity of Woody Species in Study Plots of Olokemeji Forest Reserve, Ogun State, Nigeria

\begin{tabular}{lcccccc}
\hline \multicolumn{1}{c}{ Diversity Indices } & FT1 & FT2 & HP & UP & AP1 & AP2 \\
\hline Taxa & 1 & 1 & 5 & 4 & 1 & 1 \\
Individuals & 40 & 45 & 40 & 50 & 4 & 3 \\
Dominance & 1 & 1 & 0.29 & 0.75 & 1 & 1 \\
Species Richness & 0 & 0 & 0.71 & 0.25 & 0 & 0 \\
Shannon Index & 0 & 0 & 1.36 & 0.54 & 0 & 0 \\
Evenness & 1 & 1 & 0.78 & 0.43 & 1 & 1 \\
\hline
\end{tabular}

Footnote: Frequently Burnt Plot $=$ FT; Harvested Plot $=$ HP; Unharvested Unburnt Plot $=$ UP; Arable Plot $=$ AP

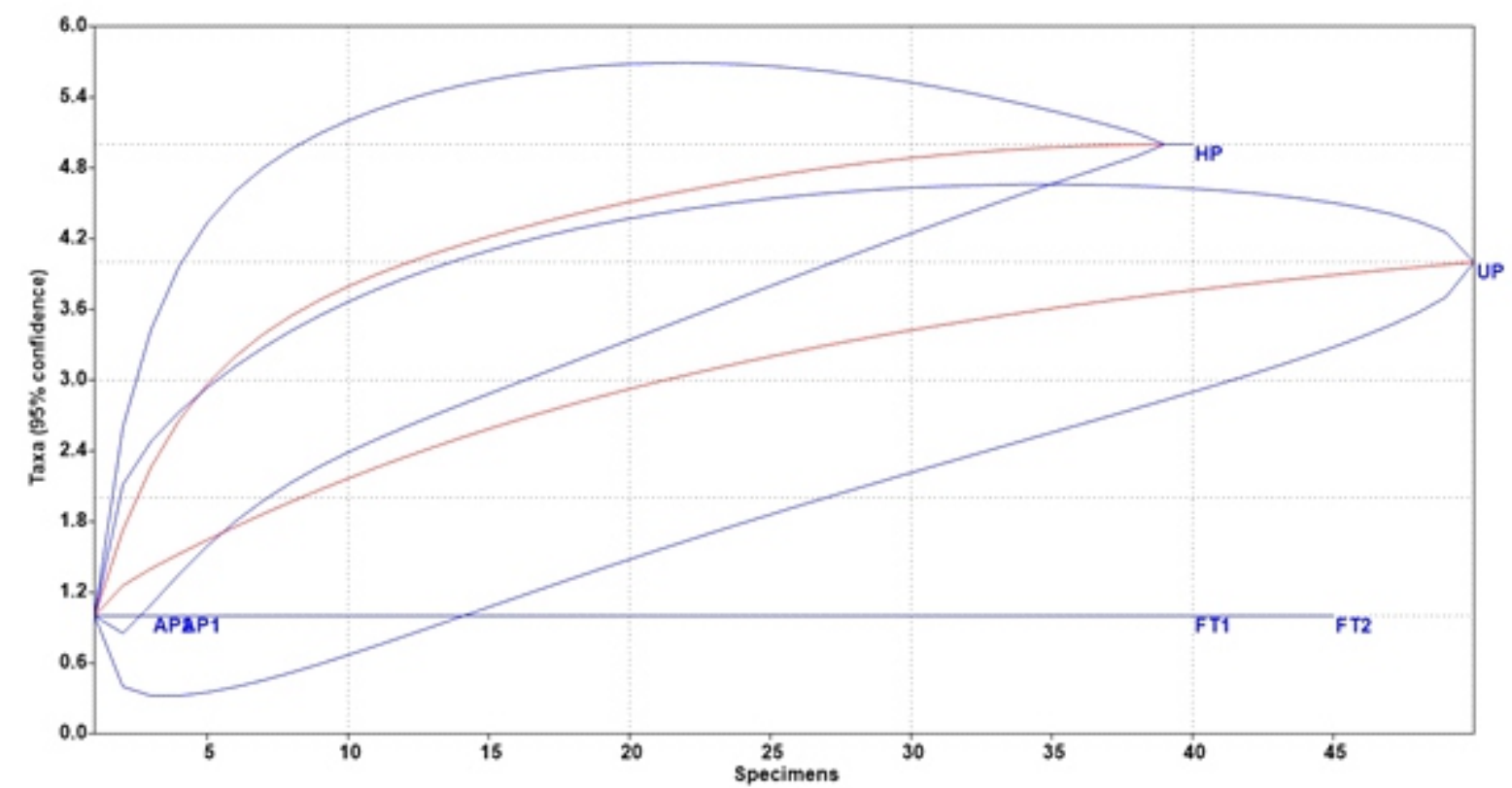

Footnote: Frequently Burnt Plot = FT; Harvested Plot = HP; Unharvested Unburnt Plot $=$ UP; Arable Plot $=$ AP

Figure 2: Rarefaction Curve for Species Richness of Selected Study Plots at Olokemeji Forest Reserve

\section{DISCUSSION}

The total number of tree stands enumerated at the randomly selected plots of Olokemeji forest reserve is one hundred and eighty two, which belongs to five families with Fabaceae having the highest number of species. Frequently Burnt Plot 2, Unharvested Unburnt Plot, Frequently Burnt Plot 1 and Harvested Plot had forty five, forty three, forty and fifteen abundance of Tectona grandis respectively. Other woody flora encountered at the study plots are: Albiz̧ia sygia, Albizia lebbeck, Delonix regia, Gliricidia sepium, Anogeissus leiocarpus and Azadiracbta indica. The species composition of the woody flora was low, suggesting inadequate stocking density for woody species and presence of anthropogenic activities in the forest or stand removal due to anthropogenic activities like seedling erosion due to uncontrolled bush fire and farming activities (Ogunleye et al., 2004). 
The relative importance value of the plants from each of the study plots reflected that Frequently Burnt Plot 2 had the highest relative importance value (RIV) for Tectona grandis at 17.22 this could be attributed to the higher seed recruitment as a result of frequent burning and also fire resistance nature of Tectona grandis in this particular plot. This is followed by Unharvested Unburnt Plot which had a RIV of 16.45 and Frequently Burnt Plot 1 recorded 15.3 as relative importance value of Tectona grandis. Harvested Plot had the least relative importance value for Tectona grandis (5.73) this could be attributed to deforestation.

Of great significance is the fact that seven tropical tree species were identified in the six study plots which revealed the low biodiverse nature of the ecosystem which corresponds with low tree species richness recorded in this study and which is lower than the species richness observed in similar ecosystems in southern Nigeria, for instance, Akure Ofosu Forest reserve found in Ondo state (Adekunle et al., 2013; Oluwatosin and Jimoh, 2016).

For the species diversity of the study plots, Unharvested Unburnt Plot had the highest abundance of trees and could be as a result of the plot not being harvested for about three years to the study. Dominance index observed across the study plot depicts that a particular tree species (Tectona grandis) was dominating each of the study plots, this could be as a result of its abundance in the plantation forest and this means there is very low species richness and the same applies to the Shannon-Weiner index across the study plots. This is contrary to the species diversity obtained for similar forest reserves for example, Oban Forest Reserve, Nigeria had 3.80 as reported by Aigbe and Omokhua (2015) and 3.74 reported by Adekunle et al. (2013) for Akure Forest Reserve, Nigeria.

\section{CONCLUSION}

There is a high level of anthropogenic interference at Olokemeji forest reserve which greatly reflected in the species diversity and composition of the woody flora of the six study plots assessed in this study. Reforestation should be carried out in those plots as soon as possible to restore the forest ecosystem in order to serve ecosystem functions especially for the purpose of combating global climate change. Indiscriminate logging of trees as fuel wood should be greatly curtailed and substituted by the neighbouring communities. Burning activities should be properly regulated to prevent the loss of biodiversity. The government should subsidise the price of other fuel sources for the populace in order to reduce the rate at which trees are logged for fuel wood by the neighbouring communities.

\section{REFERENCES}

Adekunle, V. A. J. 2006. Conservation of tree species diversity in tropical rainforest ecosystem of south-west Nigeria. Journal of TropicalForest Science, 18(2): 91-101.

Adekunle, V. A. J, Olagoke, A. O., Akindele, S. O. 2013. Tree species diversity and structure of a Nigerian strict nature reserve. Tropical Ecology, 54:275-289.

Aigbe, H. I., and Omokhua, G. E. 2015.Tree Species Composition and Diversity in Oban Forest Reserve, Nigeria.Journal of Agricultural Studies, 3: 10-24.

Akinsoji, A. and Sowemimo, E. 2005. Effects of prescribed burning on bacterial and fungal communities of top soil in Olokemeji Forest Reserve, Nigeria. The Ekologia, 3(2): 13-19.

Amonum, J. I., Jonathan, B. A., Japheth, H. D., 2019. Structure and diversity of tree species at the College of Forestry and Fisheries, University of Agriculture Makurdi, Benue State, Nigeria. International Journal of Forestry and Horticulture (IJFH), 5(1):20-27.

Aregheore, E. M. 2009. Country pasture/forage resource profiles Nigeria. Food and Agriculture Organization of the United Nations (FAO) Rome Italy Pp 42.

Athua, E. M and Pabi, O. 2013. Tree species composition, richness and diversity in the northern forest-savanna ecotone of Ghana. Journal of Applied Biosciences, 69:5437-5448.

Bajpai, O., Suman, S. and Upadhyay, N. 2017. Ecological exploration of Kuwana forest, a tropical moist deciduous forest of eastern Terai India. Annals of Plant Sciences, 6(12): 1811-1816. 
Feyera, S. 2006. Biodiversity and ecology of afromontane rain forests with wild Coffee arabica $L$. populations in Ethiopia. Ecology and Development Series No. 38, CuvillierVerlag, Gottingen.

Feyera, S. and Denich, M. 2006. Effects of wild coffee management on species diversity in the Afromontane rainforests of Ethiopia. Forest Ecology \& Management, 232(3): 68-74.

Getachew, T. and Demel, T. 2005. The influence of logging on natural regeneration of woody species in Harena Montane Forest, Ethiopia. Ethiopian Journal of Biological Science, 4(1): 59-73.

Hammer, O. 2011. Paleontological statistics version 2.08. Natural History Museum, University of Oslo. 210pp.

Hopkins, S. B. 1972. The Olokemeji Forest Reserve II. The local history of the reserve, The Nigerian Field, 34: 171.

Hopper, D. U., Chapin, F. S., Ewel, J. J., Hector, A., Inchausti, P., Lavorel, S., Lawton, J. H., Lodge, D. M., Loreau, M., Naeem, S., Schmid, B., Setala, H., Symtad, A. J., Vandermeer, J. and Wardle, D. A., 2005. Effect of biodiversity on ecosystem functioning: A consensus of current knowledge. Ecological Monographs, 75(1):335.

Hutchinson J. and Dalziel J. M., 1954. Flora of West Tropical Africa, vol. 1, $2^{\text {nd }}$ ed. Crown Agents for Overseas, London, pp. 264281

Kent, M. and Coker, P. 1992: Vegetation description and analysis: a practical approach. Belhaven press London. pp. 167-169.

Magurran, A. E. 2004: Measuring biological diversity. Blackwell Publishing, Boston. Pp 121-126.

Ogunleye, A. J., A. O., Ojo, L.O. and Aduradola, A.
M. 2004. Impact of farming activities on vegetation in Olokemeji forest reserve, Nigeria, Global Nest: The International Journal, 6 (2):131-140.

Olubode, O. S., Awodoyin, R. O., and Ogunyemi, S. (2011). Floral diversity in the wetlands of Apete River, Eleyele Lake and Oba Dam in Ibadan, Nigeria: Its implication for Biodiversity Erosion. West African Journal of Applied Ecology, 18:109-119.

Oluwatosin, B and Jimoh, S. O. 2016. Pattern of plant species diversity in a dry forest ecosystem of Nigeria, Journal of Forestry Research and Management, 13:31-47.

Ozcelik R. Gul, A. U.. Merganič, J. and Merganičová K. 2008. Tree species diversity and its relationship to stand parameters and geomorphology features in the eastern Black sea region forests of Turkey.

Spellerberg, I. F. 1991: monitoring Ecological change. New York USA, Cambridge University.112-140pp.

Stephane, B., Richard, C. Philippe, L. Laurent, B. and Frederic, G. 2009. Improving biodiversity indicators of sustainable forest management: Tree genus abundance rather than tree genus richness and dominance for understory vegetation in French lowland Oak Hornbeam forests. Forest Ecology and Management, 2585: 5176-5186.

Tadesse, W. 2008. Floristic composition environmental factors characterizing coffee forests in southwest Ethiopia. Forest Ecology and Management, 255(7): 2138-2150.

Yonas, Y. 2001. Status and prospects of Forest policy in Ethiopia. In: Imperative problems associated with forestry in Ethiopia. Workshop Proceedings, Biological Society of Ethiopia, Addis Ababa, pp. 9-30. 